\title{
The Development of a Free Radiological Anatomy Software Teaching Tool
}

\author{
Desarrollo de un Software Libre de Anatomia Radiológica \\ como una Herramienta de Enseñanza
}

\author{
Marcus Oliveira ${ }^{1}$; Paulo Geambastiani ${ }^{2,3}$; Guillermo Lopez ${ }^{1}$; Mateus Cambui ${ }^{1}$; Carlos Ubeda ${ }^{4}$ \& Sibusiso Mdletshe ${ }^{5}$
}

OLIVEIRA, M.; GEAMBASTIANI, P.; LOPEZ, G.; CAMBUI, M.; UBEDA, C. \& MDLETSHE, S. The development of a free radiological anatomy software teaching tool. Int. J. Morphol., 37(1):205-211, 2019.

SUMMARY: The purpose of this research was to develop a free radiological anatomy software for radiologic anatomy education to assist students and professionals in health science. The study was divided into two phases: image acquisition and software development. The first phase was to obtain plain radiographic images and computed tomographic (CT) scans of an anthropomorphic phantom of head and neck. In addition, plain radiographic images of an anthropomorphic phantom of the chest were obtained. The second phase was the development of the anatomy software as an ImageJ macro. The software was developed through the insertion of the radiologic anatomy landmarks into the images that were obtained and application of multiple choice questions. The software was then tested for usability by getting the professors to answer the multiple choice questions. The software presented radiologic anatomy from 1) Head projections: Waters view, Towne view, Caldwell view, Lateral view, Submentovertex, PA view; 2) Thoracic Spine projections: AP and Lateral View and 3) Chest: PA view, Lateral and Oblique. Tomographic imaging presented one hundred radiologic landmarks of head. In total, there were 354 questions. A final report containing the score of correct answers, as well as the user ID, Date and Time of the test were showed. The test were available in three languages (Spanish, English and Portuguese). A user-friendly and inexpensive software was developed and presented. Students and professionals from several countries are able to practice, repeatedly, the recognition of radiologic anatomical landmarks.

KEY WORDS: Anatomy; Radiology education; Education technology; Learning.

\section{INTRODUCTION}

Radiography plays an important role in the health care services and interacts in a multidisciplinary and interdisciplinary way with various professions (including nursing and other medical professions). Obtaining skills to understand radiography becomes an instrumental competence, necessary and indispensable to the professional of radiography (Challen, 2010). Maintaining workforce capacity, whilst reacting to the latest clinical demands on radiographer training, is a key responsibility of radiography educators (England et al., 2017).

The European Federation of Radiographer Societies (EFRS), educational wing, strongly recommends the dissemination and publication of materials and knowledge, including the promotion and development of all levels of radiography education. Radiography education in the European community is organized in different ways ranging from no formal education program to university graduate and postgraduate courses. However, there is a great concern in standardizing the educational level, as well as in accrediting training for radiography professionals (Prentakis et al., 2016).

E-learning has been increased as teaching method since 2000, and it has been suggested as an accessible high-quality education method (White \& Cheung). In addition, it has been overcoming time and geographic limitations. Most universities and education professionals are supporting this paradigm shift in education, including radiography education.

\footnotetext{
${ }^{1}$ Department of Heath Technology and Biology, Federal Institute of Bahia, Salvador, Bahia, Brazil.

${ }^{2}$ Radiology Technologist, Cardio Pulmonar Hospital, Salvador, Bahia, Brazil.

${ }^{3}$ EBSERCH, Hospital Universitário Prof. Edgar Santos, Salvador, Bahia, Brazil.

${ }^{4}$ Medical Technology Department, Health Sciences Faculty, Universidad de Tarapacá, Arica, Chile.

${ }^{5}$ HOD: Medical Imaging and Radiation Sciences Department (MIRS),Teaching Advancement at University (TAU) Fellow, Faculty of Health Sciences, University of Johannesburg, Johannesburg, South Africa.
} 
Over the last few years there has been a shift in radiography education with a move to align to the technological advancements and health education trends e.g. the use of simulated learning. Among key shifts is the use of technology for teaching students within the radiography curriculum which is critical because technology can reduce error rates while decreasing administration time and increasing quality standards. Simultaneously, Anatomy education is at the forefront of utilizing technological advancements to increasingly develop learning environments. The technology integration into anatomy education has enhanced the student education improvement (Clunie et al., 2018).

Manufacturers of medical imaging devices also provide courses and credits based on this technology (ISRRT, 2004; American Registry of Radiologic Technologists, 2018) Usually, it assists continued education and maintaining professional skills as required by radiologic associations. According to challenges and effort to find a proper learning method, although there are limitations for e-learning implementation, it may be considered as an alternative strategy for traditional classes (White \& Cheung).

According to Pinto et al. (2011) the training of students using suitable approaches to identify radiological anatomy accurately is important. This training may reduce the diagnostic errors that are often related to unrecognized or unreported abnormalities which may be associated with high morbidity. Therefore, the aim of this study was to develop a free radiological anatomy software for radiologic anatomy education to assist students and professionals in health science.

\section{MATERIAL AND METHOD}

This study was conducted at the Federal Institute do Bahia, Brazil, as a collaborative project between the research group of radiology technology and Hospital in Bahia, Brazil, to design a tool for radiologic anatomy education to assist radiographers/radiologic technologist students and professionals.

This study was divided into two phases: image acquisition and software development (Fig. 1).

Phase 1: Image Acquisition. The images of an adult anthropomorphic phantom of head and neck (Radiation Support Devices, model RS-230) were obtained in Multix B Siemens x-ray unit and a Siemens Somatom Spirit CT equipment. In addition, an anthropomorphic phantom of chest (Radiation Support Devices, model RS-111) was also imaged using the same $\mathrm{X}$-ray equipment. A computed radiography (CR) was used to obtain the digital radiographic images which was achieved by using a reader and two cassettes $(35 \mathrm{x} 43 \mathrm{~cm}, 24$ x $30 \mathrm{~cm}$ ). Furthermore, 13 radiographic projections were performed (Table I). These radiographic projections were used owing to the phantom characteristics and limitations. However, in this study, the most frequent radiographic projections used in hospital or clinics were included. The tomographic images were reconstructed in axial plane and bone window. The scan protocol used is shown in Table II. Figure 2 demonstrates how the phantoms were set up for image acquisition.

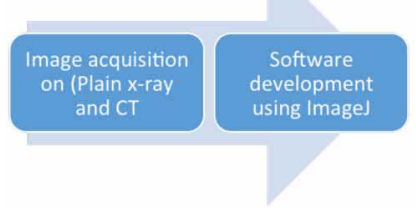

Fig 1. Study design.
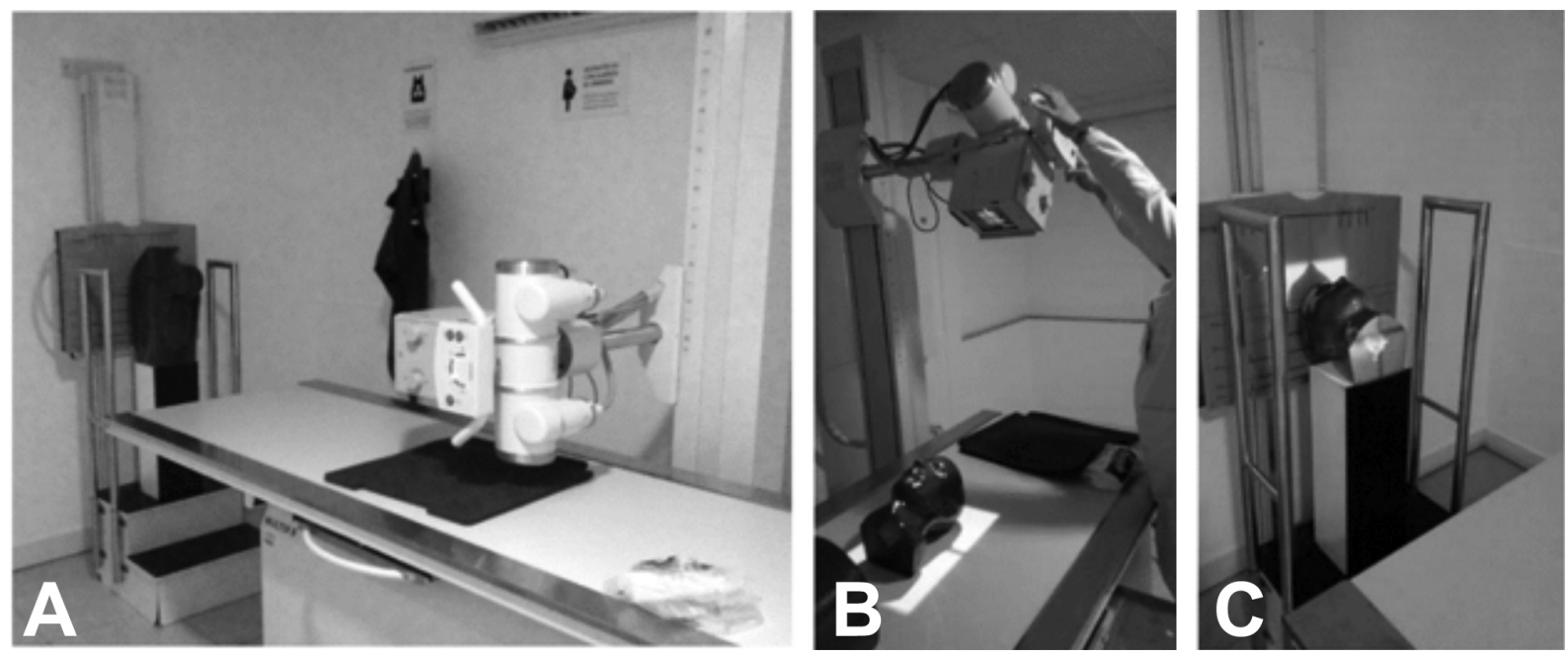

Fig 2. Radiographic projections a) Lateral view of Chest, b) Towne view, c) Submentovertex view. 

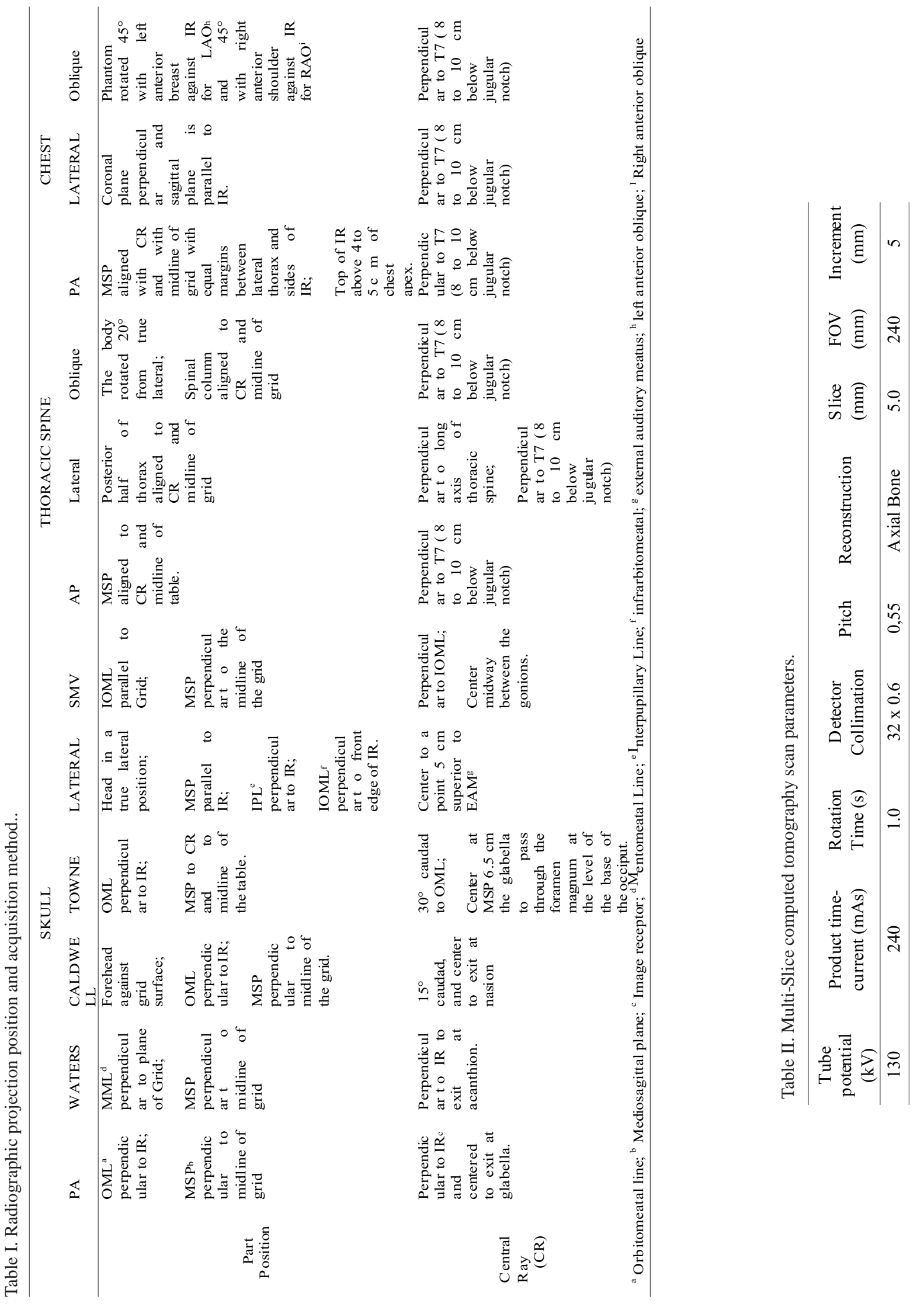
Phase 2: Software development. The software was developed using ImageJ which is a free software accessible via the internet (National Institutes of Health, USA). This is an inexpensive method, as it does not require a user license. Besides, it allows the development of macros, which assist to perform tasks automatically.

After the image acquisition, DICOM (Digital Imaging and Communications in Medicine, 2019) files were converted to TIFF. This was followed by the insertion of the arrows and numbers indicating the anatomical structures. This was done by a professor in radiology. Thereafter, a template was created relating the structure name according to arrow indication. The data was revised by three experienced professors (Professor 1:20 years, Professor 2:10 years, Professor 3: 10 years) of anatomy who have experience in radiographic and tomographic images. In this digital environment, radiological anatomy reference points were shown and multiple choice questions were applied. These questions were presented for anatomical structure recognition testing by users. Besides, four alternatives were shown as answers, however just one was correct. The software was developed in three languages (Portuguese, Spanish and English).

\section{RESULTS}

The software presented radiologic anatomy from 13 radiographic views of the head, neck and chest. On the other hand, CT images presented more than one hundred anatomic landmarks of the head (Fig. 3). In total 354 radiologic anatomy references and questions were obtained and performed, respectively.

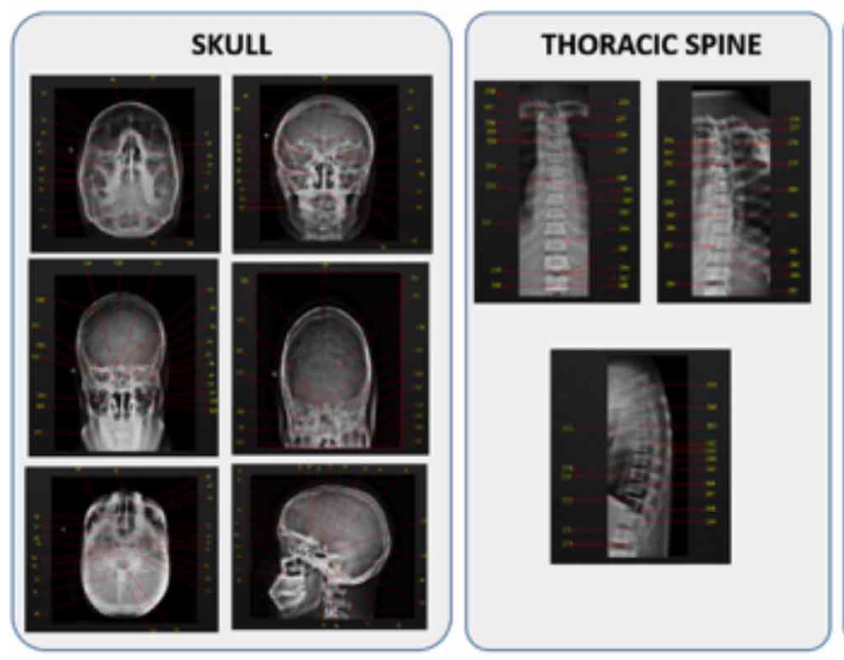

Fig 3. Radiographic and CT imaging.
The usability of the software was tested by getting a group of professors to answer the multiple choice questions. After the user's language selection, the field of identification have to be fitted, image modality and anatomy (spine, head or chest) selected and, then the radiological projection chosen (Fig. 4). The image and questions were shown. In the end of evaluation, a reported was presented containing date and time of evaluation, User name and score. The software indicated where the user incorrectly identified the anatomy (Fig. 5).

\section{DISCUSSION}

The integration of multimedia and interactivity into electronic environment has allowed valuable support for radiography teaching and continuing education (Pinto et al., 2008).

Educational strategies have to be applied for improvement of the learning process. Currently, lecture courses do not provide enough contact time for deeper learning activities. This results in limitation of students' learning performance. Furthermore, students become passive recipients of large amounts of information, leaving them with limited mental capacity to be involved with classes (Cook, 2014).

According to Xiberta \& Boada (2016) Microsoft PowerPoint is used in more than $80 \%$ of their anatomy and radiology classes. E-learning platform has been used to overcome the limitation of the traditional educational methods. Moreira et al. (2015) developed an e-learning course on breast imaging for radiographers. They concluded that it was effective and highlighted the need for continuing
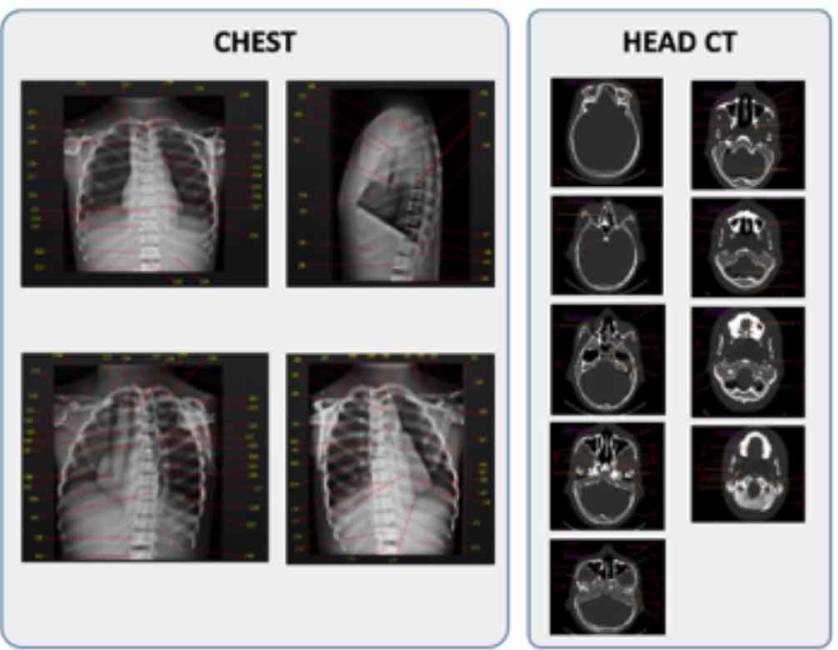


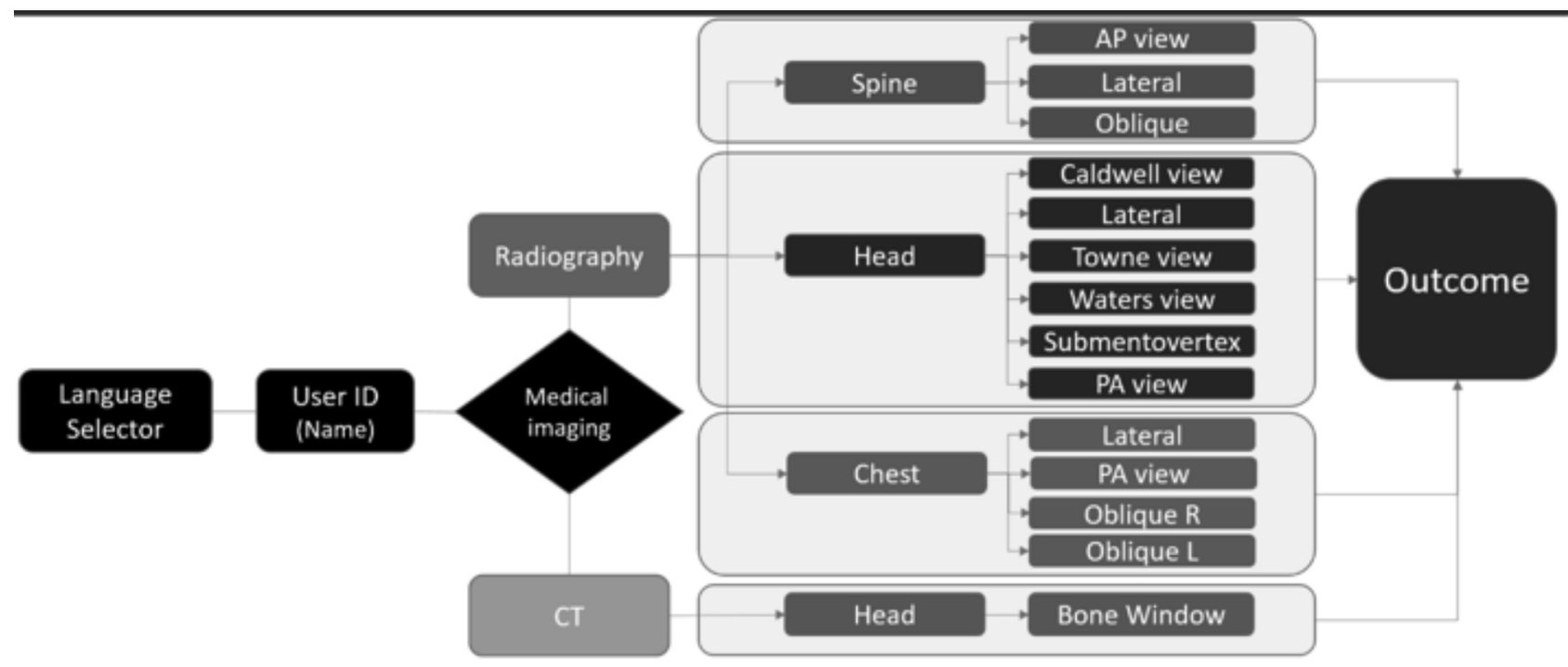

Fig 4. Software flowchart.

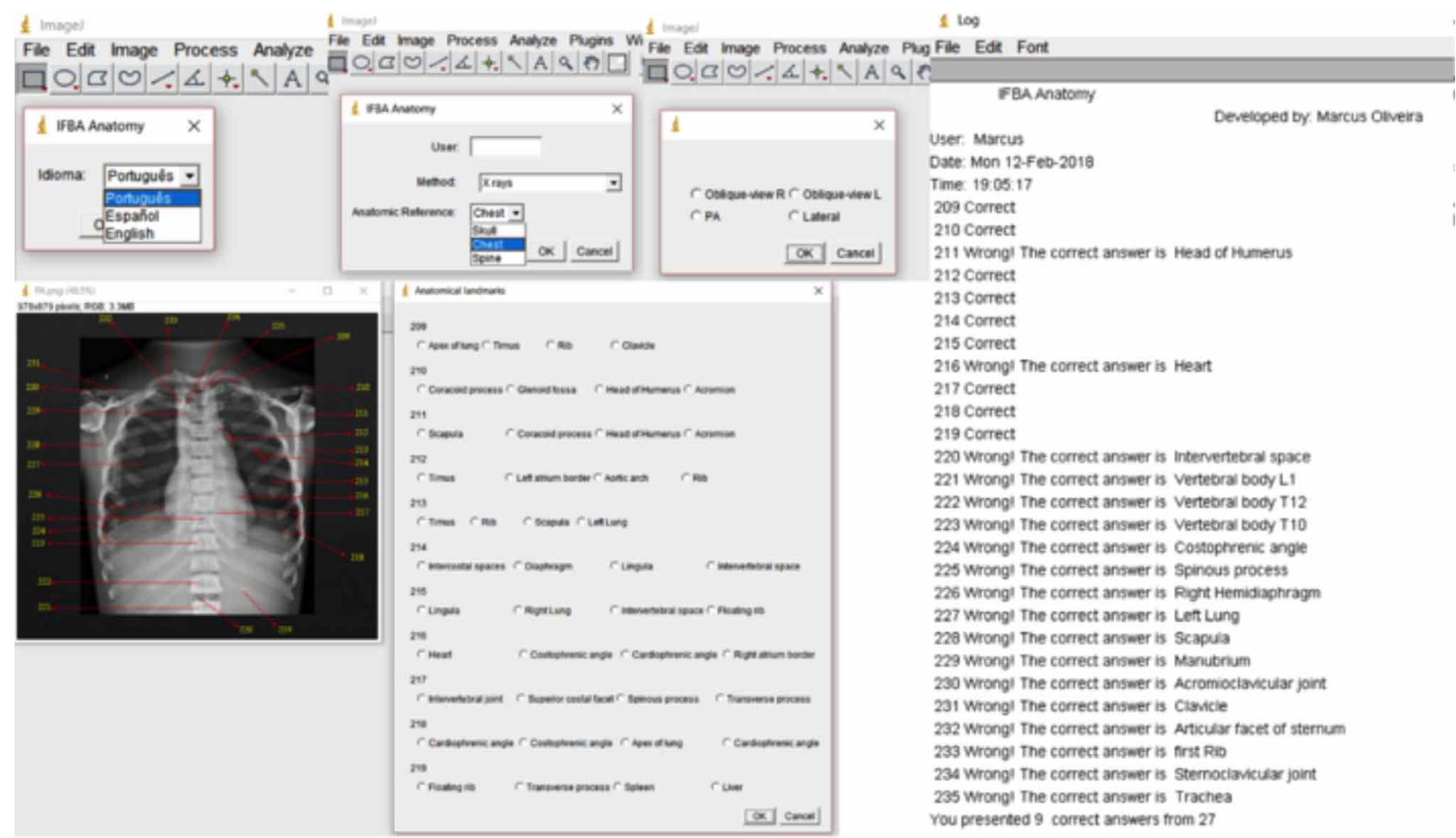

Fig 5. Screenshot of software and test result.

education. According to Cook, the e-learning method led to a reduction of delayed self-study and consequent amassed information before exams. Other platforms were developed to assist in radiological subjects in an on-line environment Eg. MyPacs (Weinberger et al., 2002), COMPARE (Grunewald et al., 2003), KICLA (Rowe et al., 2014) and RadStax (Colucci et al., 2015). There is a limitation with radiology education platform because usually e-learning courses are not presented in practical classes. Moreover, the content creation is high time consuming (Roe et al., 2010; Xiberta \& Boada).

In this study, a free radiological anatomy software as a teaching tool was presented. ImageJ is an open-source software and works independently of the operating system. Taking into account that Portuguese, English and Spanish 
are widespread languages spoken around the world, the use of this software could assist teachers and students at no cost. According to Zafar et al. (2014), sustainable educational models generate positive implications supporting the idea of lifelong learning, emphasizing that combined forms of learning are even more effective.

E-Learning efficiency is related to reliability, functionality, user friendliness of technological tool for the accomplishment of a purpose (Pójanowicz et al., 2014). The radiologic anatomy software may be considered an extremely accessible tool. Moreover, this software will assist to reduce the practice of working intensively, to absorb a large volume of informational material in a short amountsof time by students. The students can practice, exhaustively, the recognition of radiological anatomy landmarks, everywhere and independently of internet. It could also assist with continuing education for professionals.

A user-friendly and inexpensive software was presented. Radiographers, students and professionals from several countries are able to repeatedly practice, the recognition of radiologic anatomical landmarks. This software can be applied as a feasible technological tool for enhancing learning environment.

\section{ACKNOWLEDGEMENTS}

The authors thank the Federal Institute of Bahia LAFIR and GTecRad (Grupo de Pesquisa em tecnologia em Radiologia), Brazil; Universidad de Tarapacá, Arica, Chile; Faculty of Health Sciences, University of Johannesburg, Johannesburg, South Africa for their support in conducting this study.

The readers can obtain the software contacting the first author and developer by email: marcusradiology@gmail.com

OLIVEIRA, M.; GEAMBASTIANI, P.; LOPEZ, G.; CAMBUI, M.; UBEDA, C. \& MDLETSHE, S. Desarrollo de un software libre de anatomia radiológica como una herramienta de enseñanza. Int. J. Morphol., 37(1):205-211, 2019.

RESUMEN: El propósito de esta investigación fue desarrollar un software gratuito de anatomía radiológica para la educación de anatomía radiológica para ayudar a estudiantes y profesionales de ciencias de la salud. El estudio se dividió en dos fases: adquisición de imágenes y desarrollo de software. La primera fase consistió en obtener imágenes radiográficas simples y tomografías computarizadas (TC) de un fantasma antropomórfico de cabeza y cuello. Además, se obtuvieron imágenes radiográficas simples de un fantasma antropomórfico del tórax. La segunda fase fue el desarrollo del software de anatomía como una macro ImageJ. El software se desarrolló a través de la inserción de los puntos de referencia de la anatomía radiológica en las imágenes que se obtuvieron y la aplicación de preguntas de opción múltiple. Luego, se probó la usabilidad del software haciendo que los profesores respondieran las preguntas de opción múltiple. El software presentó la anatomía radiológica de 1) Proyecciones de la cabeza: vista de aguas, vista de Towne, vista de Caldwell, vista lateral, Submentovertex, vista de PA; 2) proyecciones de la columna torácica: vista AP y lateral y 3) Cofre: vista de PA, lateral y oblicua. Las imágenes tomográficas presentaron cien puntos de referencia radiológica de la cabeza. En total, hubo 354 preguntas. Se mostró un informe final con la puntuación de las respuestas correctas, así como la identificación del usuario, la fecha y la hora de la prueba. Las pruebas estaban disponibles en tres idiomas (español, inglés y portugués). Se desarrolló y presentó un software fácil de usar y de bajo costo. Estudiantes y profesionales de varios países pueden practicar, repetidamente, el reconocimiento de puntos de referencia anatómicos radiológicos.

PALABRAS CLAVE: Anatomía; Radiología educacional; Tecnología educacional; Enseñanza.

\section{REFERENCES}

American Registry of Radiologic Technologists (ARRT). St. Paul, The American Registry of Radiologic Technologists, 2018. Available from: https://www.arrt.org/docs/default-source/Governing-Documents/ continuing-education-requirements.pdf

Challen, V. Radiography Education in Europe, Vision of HENRE (Higher Education Network for Radiography Education). Vienna, European Association of Nuclear Medicine, 2010. Available from: https:// www.eanm.org/content-eanm/uploads/CTE-Archive/2010/Lunch/ lunch_1.pdf

Clunie, L.; Morris, N. P.; Joynes, V. C. T. \& Pickering, J. D. How comprehensive are research studies investigating the efficacy of technology-enhanced learning resources in anatomy education? A systematic review. Anat. Sci. Educ., 11(3):303-19, 2018.

Colucci, P. G.; Kostandy, P.; Shrauner, W. R.; Arleo, E.; Fuortes, M.; Griffin, A. S.; Huang, Y. H.; Juluru, K. \& Tsiouris, A. J. Development and utilization of a web-based application as a robust radiology teaching tool (radstax) for medical student anatomy teaching. Acad. Radiol., 22(2):247-55, 2015

Cook, D. A. The value of online learning and MRI: finding a niche for expensive technologies. Med. Teach., 36(11):965-72, 2014.

Digital Imaging and Communications in Medicine (DICOM). Arlington, National Electrical Manufacturers Association, 2019. Available from: https://www.dicomstandard.org/ 
England, A.; Geers-van Gemeren, S.; Henner, A.; Kukkes, T.; Pronk-Larive, D.; Rainford, L. \& McNulty, J. P. Clinical radiography education across Europe. Radiography (Lond.), 23 Suppl. 1:S7-15, 2017.

Grunewald, M.; Heckemann, R. A.; Gebhard, H.; Lell, M. \& Bautz, W. A. COMPARE radiology: creating an interactive Web-based training program for radiology with multimedia authoring software. Acad. Radiol., 10(5):543-53, 2003.

Moreira, I. C.; Ventura, S. R.; Ramos, I. \& Rodrigues, P. P. Development and assessment of an e-learning course on breast imaging for radiographers: a stratified randomized controlled trial. J. Med. Internet Res., 17(1):e3, 2015.

Pinto, A.; Acampora, C.; Pinto, F.; Kourdioukova, E.; Romano, L. \& Verstraete, K. Learning from diagnostic errors: a good way to improve education in radiology. Eur. J. Radiol., 78(3):372-6, 2011.

Pinto, A.; Selvaggi, S.; Sicignano, G.; Vollono, E.; Iervolino, L.; Amato, F.; Molinari, A. \& Grassi, R. E-learning tools for education: regulatory aspects, current applications in radiology and future prospects. Radiol. Med., 113(1):144-57, 2008.

Pójanowicz, W.; Roszak, M.; Koodziejczak, B. \& Bre borowicz, A. An Analysis Of The Effectiveness and Quality of E-Learning in Medical Education. In: Smyrnova-Trybulska, E. (Ed.). E-learning and Intercultural Competences Development in Different Countries. Katowice, Studio NOA, University of Silesia, 2014. pp.177-96.

Prentakis, A. G.; Stefanoyiannis, A. P.; Georgiadis, K.; Coleman, L.; Foley, S. J.; Herlig, D.; Kollas, P.; Kowalik, A.; Tomczak, J. \& Chatziioannou, S. N. Education, training, and professional issues of radiographers in six European countries: a comparative review. J. Eur. CME, 5(1):31092, 2016

Roe, D.; Carley, S. \& Sherratt, C. Potential and limitations of e-learning in emergency medicine. Emerg. Med. J., 27(2):100-4, 2010.

Rowe, S. P.; Siddiqui, A. \& Bonekamp, D. The key image and case log application. Acad. Radiol., 21(7):916-30, 2014.

Weinberger, E.; Jakobovits, R. \& Halsted, M. MyPACS.net: a Web-based teaching file authoring tool. A. J. R. Am. J. Roentgenol., 179(3):57982, 2002.

White, P. \& Cheung, A. K. Y. E-learning in an undergraduate radiography programme: Example of an interactive website. Radiography, 12(3):244-52, 2006.

Xiberta, P. \& Boada, I. A new e-learning platform for radiology education (RadEd). Comput. Methods Programs Biomed., 126:63-75, 2016.

Zafar, S.; Safdar, S. \& Zafar, A. N. Evaluation of use of e-Learning in undergraduate radiology education: a review. Eur. J. Radiol., 83(12):2277-87, 2014.
Corresponding author:

Marcus Vinicius Linhares de Oliveira

Department of Health Technology and Biology

Federal Institute of Bahia Emídio dos Santos - s/n -

Salvador

Bahia

BRAZIL

E-mail: marcusradiology@gmail.com

Received: 09-08-2018

Accepted: $17-10-2018$ 